ESJ Social Sciences

\title{
Female Education and Contraceptives Use in Nigeria
}

\author{
Saheed O. Olayiwola \\ Department of Economics, \\ Federal University of Technology, Akure, Nigeria \\ Bayo L.O. Kazeem \\ Department of Banking and Finance, Osun State University, Nigeria \\ Fuein, Vera Kum \\ Faculty of Economics and Management Science \\ University of Bamenda, Cameroon
}

Doi:10.19044/esj.2021.v17n32p366

Submitted: 31 July 2021

Accepted: 22 September 2021

Published: 30 September 2021
Copyright 2021 Author(s)

Under Creative Commons BY-NC-ND

4.0 OPEN ACCESS

Cite As:

Olayiwola S.O., Kazeem B.L.O. \& Fuein V.K. (2021). Female Education and Contraceptives Use in Nigeria. European Scientific Journal, ESJ, 17 (32), 366.

https://doi.org/10.19044/esj.2021.v17n32p366

\section{Abstract}

Contraceptive use is considered important for protecting women's health and rights, influencing fertility and population growth. This study examined the impact of female education on the use of contraceptives and fertility rate in Nigeria using 2013 and 2018 cohorts of Demography and Health Survey Data. The survey covers women ages 15 to 49 years. The study shows that women's education, income level, and cultural value are important in explaining women's reproductive behaviour. The results reveal that female education has a positive significant effect on contraceptives use and a significant negative effect on fertility rate. The contraceptives use and fertility models show that the effects become stronger with an increase in the level of education. Notably, the study shows no significant difference in the behavioural pattern of the factors that influenced contraceptive use and fertility rate in the 2013 and 2018 cohorts of demography and health survey data. The study concludes that female education is vital in encouraging the use of contraceptives and controlling the fertility rate. Hence, the government should invest more in women education to increase women's use of contraceptives, control fertility, and population growth, protect women's health and stimulate sustainable economic development. 
Keywords: Education, Contraceptives Use, Fertility

\section{Introduction}

Unexpected pregnancies represent a major public health challenge for women of childbearing age in developing countries. Contraceptives use is considered essential for protecting women's health and rights, influencing fertility and population growth, and promotes economic development. Globally, contraceptives use had prevented about 2.7 million infant deaths and women's use of contraceptives has improves their education and employment opportunities (Darroch, Dingh \& Dadeau, 2008; Sonfield, 2013). This in turn, improves income, family stability, mental health and happiness, as well as the well-being of children. In 2012, about 168,000 women in Sub-Saharan Africa died as a result of pregnancy or childbirth; 62,000 of these women did not want pregnancy in the first place. Also, unmet need for contraception was responsible for 19 million unplanned pregnancies, 8 million unplanned births, 5 million abortions, 2 million miscarriages, 555,000 infant deaths and 255,000 unplanned pregnancies (Guttmacher Institute \& UNFPA, 2012). However, studies have shown that female education is associated with a decrease in fertility (Adjei et.al., 2014, Schultz, 2008; Sackey, 2005; Vavrus \& Larsen, 2003). Schultz, (2008); Sackey, (2005); Vavrus \& Larsen (2003) argued that slow but steady improvements in the distribution of schooling explained about 70 percent fertility decline from the 1935-39 birth cohorts to the 1951-53 cohorts. These authors' also documented other important factors influencing fertility as age at first marriage, husband's education, and earnings among others.

In Nigeria, the high annual population growth rate has been a major concern for population experts and policymakers. The 2011 multiple indicator cluster survey revealed that contraceptive prevalence rate was $17.5 \%$ and the unmet need for contraception was 19.4\% (NBS, 2011). In addition, in 2013 and 2018 Nigeria Demographic and Health Survey (NDHS), only 10\% of married women use a modern family planning method and 5\% use traditional method, while only $40 \%$ of sexually active single women use modern method of family planning (NDHS, 2013; 2018). The Nigerian Urban Reproductive Health Initiative (NURHI) in a mid-line 2012 report revealed that there is high rate of unplanned pregnancies, unsafe abortions and sexually transmitted diseases among young adults. The 2012 Nigeria's Midterm Survey also shows that the common reasons for not using contraceptives include lack of access to methods that meet the needs of users; health concerns and side effects; opposition from a partner for cultural or religious reasons; and problems in obtaining family planning services, including not being able to afford contraceptives. However, while there is an increase in proportion of educated 
people, the level of fertility has considerably increased globally (McCarthy, 2017). But, there appears to be scanty empirical evidence on the impact of female education on contraceptives use. This study examined the effect of female education on contraceptives use and fertility in Nigeria using 2014 and 2018 Nigeria Demographic and Health Survey (NDHS) cohorts. The rest of the study comprises of four sections. Section two covers the review of literature while section three contains research methodology. Section four present results and discussion of results and section five concludes.

\section{Review of Literature}

Contraceptives and fertility are two interrelated but distinct terms. Fertility refers to the number of live births a woman or couple can have while contraceptives use is a determinant of fertility. Contemporary studies have shown that among the reasons for having sex, having baby is the least frequent motivator for most people (Okunade et.al, 2016). Contraceptives are generally classified into traditional and modern methods. The traditional methods are abstinence, coitus interruptus and other traditional methods. Sexual abstinence is the most effective method of traditional contraception without physiological or psychological effects. Coitus interruptus is the withdrawal of penis without orgasm and without ejaculation during sexual intercourse. About 50\% of couples in western countries occasionally use this method of contraception (Theron \& Grobler, 1998). However, there is a risk of unplanned pregnancy with this method because leakage of semen into the vagina can lead to conception. Other traditional methods include herbal mixtures, tying a rope soaked in traditional medicines around the waist, burying a soiled sanitary pad until conception was desired, drinking strong coffee or tea or medicines after coitus, prolonged lactation, vaginal douching after intercourse and inserting cotton wool soaked in oil or vinegar into the vagina prior to intercourse (Wood \& Jewkes, 2000; Vlok, 2000). Modern contraceptives include barrier methods, oral contraceptives and injections (Kasner \& Tindall, 1985). Barrier methods include the use of condom, spermicides, diaphragms, cervical caps, injections and oral contraceptives.

Manjula, (2014) conceptualise education in a narrow and broad sense. In a narrow sense, education is a deliberate effort made with a definite purpose of developing certain amount of knowledge, skills, attitudes and habits in setup educational institutions. Education in this context is confined only to a few specific, deliberate, and planned efforts that have bearing on the development of the individual. Thus, in a narrow sense, education is a purposeful activity, deliberately planned for the optimum development of an individual's potentials. In a broader sense, education is a lifelong process, including experience, knowledge and wisdom an individual acquires at different stages of life through formal and informal channels. The broader 
view considers education as an act or experience that has formative or additive effect on the personality of an individual. It is assumed that education is both an instrument of social change and an investment in national development.

Adjei, Sarfo and Asiedu (2014) in their study of psychosocial factors affecting contraceptive usage in Ghana examine the relationship between some selected socio-demographic variables and current contraceptive use among Ghanaian women. The authors found that despite the remarkable efforts made in improving contraceptive prevalence rate in Ghana there are still substantial constrains to the number of users of contraceptive in the country. These constraints include education, knowledge of access to contraceptive method, knowledge of method, employment status, marital status, region of residence, fertility preference and ethnicity. Though the authors' expected a strong association between education and contraceptive use due to their findings from the previous studies. Knowledge of access to contraceptive method was however found to be the most important factor. Savage-Oyekunle (2018) in Appraisal of Nigeria's Obligation on Adolescents' Access to Sexual and Reproductive Health Care explores the responsibility of the Nigerian state towards ensuring female adolescents' access to sexual and reproductive health (SRH) care information and services especially contraceptive information and services. The study found concluded by stating the need for judicial activism and stricter monitoring of the government's activities in other to ensure that adolescents enjoy actual access to SRH care information and services.

Obomeghie, Abubakar and Abdulrahman (2018) on the empirical evidence of the impact of net-migration on total fertility rate in sub-Saharan African countries from Nigeria analysed the impact of net migration on total fertility rate in Sub-Saharan African countries using data from Nigeria. The study was as a result of the need for the sub-Saharan African countries to have a balanced fertility rate that will enable them to achieve their desired economic growth and development. The study found that net-migration positively impact total fertility rate in Nigeria. Musyoka, Korir, Omolo and Nzai (2018) on an empirical analysis of the effect of poverty on health care utilization in Kenya with use of negative binomial regression and the 2013 Kenya household expenditure and utilization survey dataset found that increase in wealth leads to reduction in poverty, hence, increase health care utilization. Other factors that had a positive effect on health care utilization were according to the study are household size, early levels of education, and distance to the nearest health facility. Russell, Rahman, Monte-Serrat and Arafat (2017) on exploring the decision-making power of Bangladeshi women of reproductive age: results from a national survey examined the decision making authority and gender role of Bangladeshi women of reproductive age group. The study found that respondents from richest background and urban 
residence and with higher educational attainment were more likely to take their own decisions. Working status and membership to NGO were also found to be significantly associated with decision making power of women. More importantly, poor attainment of primary education, low employment, and few NGO memberships were the hindrance in women empowerment in Bangladesh.

The relationship between education and fertility has a long history in the fields of economics and demography. Jejeebhoy (1995) categorizes four patterns of the relationship between education and fertility. In the first pattern, there is a straight inverse relationship between education and fertility. This pattern supports the much known hypothesis that fertility falls monotonically with increased women's years of schooling. The second pattern depicts an inverted $\mathrm{U}$ or $\mathrm{J}$ shaped curvilinear relationship. This pattern indicates that the first few years of schooling increases fertility initially, but the trend is eventually reversed. The third pattern is similar with the first one but the relationship is 7-shaped. The 7-shaped curve means that the first part of the curve is horizontal which suggests that the first few years of schooling have either no effect or produces a slight rise in fertility. The second part of the curve indicates that the curves falls dramatically which indicates that more years of schooling is inversely related to fertility. In the fourth pattern, a positive or no relationship was demonstrated. Colleran, (2014), using linear and binomial multi-level regression techniques in Poland found that community level of education rather than individual level of education reduces fertility rate in that community. Studies have hypothesized that education is related to favourable attitudes toward birth control, improved knowledge of birth control, and better spousal communication, which lead to effective use of contraception.

Ainsworth, (1996) identified four main transmission mechanisms between women's schooling, contraceptives use and fertility. These are wage effects, higher demand for child schooling, lower child mortality and more effective use of contraception. A woman's schooling not only increases her chances of entering the labour market but also leads her to command a higher wage. Among the effects of higher wage is the opportunity cost of women's time in rearing children which raises the cost of having children. Educated women are more likely to exercise the "quality-quantity trade-off" of their children, consider the benefit of their schooling and develop higher aspirations for their children's schooling. The trade-off is not a new event in the developed society, but a recent trend in some parts of Sub-Saharan African countries. The usual cited factor in explaining the link between education and contraceptives use is women's autonomy. The link between education and women's autonomy has been strongly acknowledged that studies have often used education and literacy as substitutes for women's autonomy (Riyami, Afifi \& Mabry, 2004). 
Autonomy is linked to women's decision-making power; its use may thus vary according to the context, such as the family or the workplace, and the power relations between men and women. Saleem \& Bobak, (2005) and Riyami, Afifi \& Mabry, (2004) in the studies of Asia and the Middle East focus on women's participation in household's decision-making and freedom of movement. These indicators hardly fit into the cultural context of Sub-Saharan Africa, where women generally have considerable economic independence, access to resources, freedom of movement, and decision-making power with respect to their own lands and commercial activities. Indicators that have tried to show the influence of women's autonomy through the dynamics of marital relationships have focused on spousal communication of family planning and husbands' approval/disapproval of family planning. Spousal communication is considered an indicator of power relations between couples (Blanc, 2001) and has also been associated with educational background (Blanc \& Wolff, 2001). Gage (1995) argues that spousal discussion of family planning could be a reflection of women's autonomy. Demographic Health Survey (DHS) data across sub-Saharan Africa have also shown that women who discussed family planning with their spouses were more likely to use contraception (Korra, Sharan \& Valente, 2002). Husband's education level is another factor considered important in terms of the relative difference between husband and wife (Blanc, 2001; Wolff, Blanc \& Gage, 2000). Hemmings, Lemma \& Antoni, (2008) and Korra (2002) suggest that women's education impacts on their level of knowledge, and through it their contraceptive use.

Isenberg (2003) stressed the importance of having a place of internal control. The place of internal control is a person's belief in the effectiveness of their own behaviour, rather than that of others, chance, fate or luck. Women with high level of internal control are more likely to use contraceptives. Women tend to use a more scientific standard to cope with life events, such as births and marriages, and less of the superstition and supernatural explanations that prevail in traditional societies (Isenberg, 2003).

\section{Methodology}

This study adopted microeconomic household theory of fertility as theoretical framework. The microeconomic theory of consumer behaviour assumes that an individual with a given set of tastes or preference for a range of goods (utility function) tries to maximize the satisfaction derived from consuming these goods subject to his or her own income constraint and the relative prices of all goods. Todaro and Smith (2015) posited that couple's demand for children can be treated as similar to the demand for goods and services. Fertility is seen as an answer to the couple's demand for children relative to other goods. Indeed, demand for children depends on household income, on the cost of children, and on parents' tastes or preferences for children 
relative to other goods and services that provide utility to the couple. Economic theory suggests that a higher income is expected to be associated with a greater demand for children, if children are treated as normal goods. Also, Todaro and Smith (2015) assume that the usual income and substitution effect can be applied. That is, if other factors are held constant, the desired number of children can be expected to vary directly with household income, inversely with the price (cost) of children and inversely with tastes for other goods relative. These relations can be expressed thus:

$$
C_{d}=f\left(Y, P_{c}, P_{x}, T_{x}, \ldots \ldots \ldots, n\right.
$$

Where $\mathrm{C}_{\mathrm{d}}$ is the demand for children and a function of household income $(\mathrm{Y})$, price of children $\left(\mathrm{P}_{\mathrm{c}}\right)$, prices of other goods $\left(\mathrm{P}_{\mathrm{x}}\right)$ and tastes of goods relative to children $\left(\mathrm{T}_{\mathrm{x}}\right)$. We derived two models in application of this theory. The first model analyses the determinants of contraceptives use and the second model deals with fertility. These two models are dependent on socio-economic, demographic and proximate variables. The fertility model assumes that women attempt to maximize their level of utility given all goods and services. Given this framework, the model is specified as follows:

Contr

$=f\left(E d p r i, E d s e c, E d t e r, Y_{l}, Y_{m}, Y_{h}, F_{P}, K_{n}, A g e, A g e^{2}, U r b, I n\right.$, Sib,$C u l$

Equation (2) states that contraception is a function of primary education, secondary education, tertiary education, knowledge of family planning, knowledge of ovulation cycle, age, region, income, number of siblings, and cultural traits. The fertility model in equation (3) below is specifies as a function of primary education, secondary education, higher education, family planning knowledge, contraceptives use, age, region, income, number of siblings, and cultural traits or believe thus:

Fert

$=f\left(E d p r i, E d s e c, E d t e r\right.$, Work $, Y_{l}, Y_{m}, Y_{h}$, Fam $_{P}, K_{n}$, ContrAge,Urb, Sib, Cul

The explicit form of both equation (2) and equation (3) can be stated thus:

$$
\begin{aligned}
\text { Contr }= & \beta_{0}+\beta_{1} \text { Edpr }+\beta_{2} \text { Edsec }+\beta_{3} \text { Edter }+\beta_{4} \text { work }+\beta_{5} Y_{l+} \beta_{6} Y_{m} \\
& +\beta_{7} Y_{h}+\beta_{8} \text { famP }+\beta_{9} \text { KnoV }+\beta_{10} \text { age }+\beta_{11} \text { Urb } \\
& +\beta_{12} \text { Sib }+\beta_{13} \text { Cul }+\mu_{i}
\end{aligned}
$$

$$
\begin{aligned}
\text { Fert }= & \beta_{0}+\beta_{1} \text { Edpr }+\beta_{2} \text { Edsec }+\beta_{3} \text { Edter }+\beta_{4} \text { work }+\beta_{5} Y_{l+} \beta_{6} Y_{m} \\
& +\beta_{7} Y_{h}+\beta_{8} \text { famP }+\beta_{9} \text { KnoV }+\beta_{10} \text { age }+\beta_{11} \text { Urb } \\
& +\beta_{12} \text { Sib }+\beta_{13} \text { Cul }+\beta_{14} \text { Contr }+\mu_{i}
\end{aligned}
$$


Equation (4) states that contraceptive use (Contr) depends on female primary education (Edpr), female secondary education (Edsec), female tertiary education (Edter), low-income $\left(\mathrm{Y}_{1}\right)$, middle-income $\left(\mathrm{Y}_{\mathrm{m}}\right)$, high-income $\left(\mathrm{Y}_{\mathrm{h}}\right)$, family planning knowledge (FamP), knowledge of ovulation cycle (KnoV), age of women (Age), urban resident (Urb), cultural-trait variables such as son preference $(\mathrm{Cul})$, number of siblings $(\mathrm{Sib})$ and error term $(\mu)$ representing other factors that affects contraceptives use. Also, equation (5) states that fertility depends on all variables defined in equation (4) and contraceptives use.

From Ainsworth (1996), the signs of the coefficients in the fertility model in equation (5) are opposite to those in the contraceptive model of equation (4). Therefore, the expected signs of the coefficients of the fertility model are based on the contraceptive model. If a variable has a positive sign in the contraceptive model, the same variable is expected to have a negative sign in the fertility model and vice versa. In the contraceptive model the a prior expectations are $\beta_{1}, \beta_{2}, \beta_{3}, \beta_{4}, \beta_{6}, \beta_{7}, \beta_{8}, \beta_{9}, \beta_{12},>0$, and $\beta_{5}, \beta_{10}, \beta_{11}, \beta_{13}, \beta_{14}$ $<0$ while in the fertility model the a priori expectations are $\beta_{1}, \beta_{2}, \beta_{3}, \beta_{4}, \beta_{6}$, $\beta_{7}, \beta_{8}, \beta_{9}, \beta_{12}<0$ and $\beta_{5}, \beta_{10}, \beta_{11}, \beta_{13}, \beta_{14}>0$.

\subsection{Data and Estimation Techniques}

The data for the study are drawn from the 2014 and 2018 cohorts of Nigeria Demographic and Health Survey. The two sets of the data were chosen to examine behavioural pattern changes in the determinants of contraceptives use and fertility in Nigeria over the years. The Nigeria Demographic and Health Survey (NDHS) were implemented by the National Population Commission. The resources for the conduct of the survey were provided by the United States Agency for International Development (USAID), the United Nations Population Fund (UNFPA), the United Kingdom Department for International Development (DFID) (through the Partnership for Transforming Health Systems Phase II (PATHS2), and the government of Nigeria (through the National Planning Commission) while ICF Macro International provided technical support throughout the duration of the survey. The survey data provided information on contraceptives use, maternal and child health, child survival, HIV/AIDS/STIs and reproductive health. The survey instrument, which is fairly comprehensive, asks respondents a series of questions regarding educational attainment, contraceptive use, rural/urban domicile, and fertility.

The model describing contraceptive use employs logit estimation technique. The dependent variable is the probability that a woman uses contraceptive before her first child. The fertility model which assumes that women attempt to maximize their level of utility given all goods and services utilizes negative binomial regression method. The dependent variable is the 
number of children per woman, and it is measured as count data. The independent variables are the same with those of the contraceptive model, with the exception that in the fertility model contraceptive use is among the explanatory variable. Table 1 gives a clear description of all the variables used in the study. 
Table 1: Description of the Variables

\begin{tabular}{|l|l|l|}
\hline Variables & Definition & Description \\
\hline Contr & This is the variable for contraceptive use. 1 if a woman uses contraceptive, else 0 & Dichotomous \\
\hline Fert & Fertility variable, the Total number of children born per woman & Count \\
\hline Edpr & Primary level of education. 1 if a woman has primary education, otherwise 0 & Dichotomous \\
\hline Edsec & Secondary level of education. 1 if a woman has secondary education, otherwise 0 & Dichotomous \\
\hline Edhigh & Post-secondary level of education. 1 if a woman has tertiary education, otherwise 0 & Dichotomous \\
\hline Lowincome & Lower income earners. 1 if a woman is from low income household, otherwise 0 & Dichotomous \\
\hline Middleincome & Average income earners. 1 if a woman is from average income household, else 0 & Dichotomous \\
\hline Highincome & High income earners. 1 if a woman is from high income household, otherwise 0 & Dichotomous \\
\hline FamP & $\begin{array}{l}\text { Knowledge of local family planning centre. 1 if a woman ever heard of a local family } \\
\text { planning otherwise 0 }\end{array}$ & Dichotomous \\
\hline KnoV & Knowledge of ovulatory cycle. 1 if a woman has knowledge of ovulatory cycle otherwise 0 & Dichotomous \\
\hline Age & The current age of a woman & Continuous \\
\hline Agesquared & The square of the current age of women & Continuous \\
\hline Urb & Place of residence. 1 if a woman lives in urban residency, otherwise 0 & Dichotomous \\
\hline Sib & The number of siblings a woman has & Continuous \\
\hline Cul & Son preference. 1 if a woman prefers more sons to daughters, otherwise 0 & Dichotomous \\
\hline
\end{tabular}


Table 2 shows the descriptive statistics of the Nigeria Demographic and Health Survey (NDHS) data for 2013, 2018 cohorts and both years combined. The mean and standard deviation of contraceptives use was between 0.13 to 0.15 and 0.34 to 0.37 for years 2013, 2018 and both years combined. The results show that at least women give birth to at least three children for both years with the values of 3.14 for 2013, 3.07 for 2018 and 3.09 for both years combined. This shows that the average number of live births by women did not differ significantly from 2013 to 2018. The average number of women that attains primary education was between 0.18 and 0.19 ; secondary education was between 0.33 and 0.47 and between 0.08 and 0.09 for tertiary education. The average number of women engaged in gainfully employment was between 0.68 and 2.79 . This show about $310 \%$ increase in the number of working women between 2013 and 2018. There was no significant change in the income group of women from $2013-2018$. The results show the average low-income women to be between 0.19 and 0.20 ; 0.19 and 0.21 for middle-income and between 0.18 and 0.22 for the high income women. Between 48 and 51 women knows local family planning centre while about 2 and 3 women have knowledge of their ovulatory period. An average woman was about 29 years of age and about $31-40$ of them reside in urban area. The average number of siblings for women was about 5 while about 9 to 14 women have preference for a male child. The descriptive statistics results do not show any significant change in the women reproductive behavioural pattern from 2013 to 2018 . 
Table 2: Descriptive Statistics

\begin{tabular}{|c|c|c|c|c|c|c|c|c|c|c|c|c|}
\hline \multicolumn{5}{|c|}{ Year 2013} & \multicolumn{4}{|c|}{ Year 2018} & \multicolumn{4}{|c|}{ Combined Years $(2013 \&$ 2018) } \\
\hline Variables & Mean & $\begin{array}{l}\text { Std. } \\
\text { Dev. }\end{array}$ & Min & Max & Mean & $\begin{array}{l}\text { Std. } \\
\text { Dev. }\end{array}$ & Min & Max & Mean & $\begin{array}{l}\text { Std. } \\
\text { Dev. }\end{array}$ & Min & Max \\
\hline Contr & 0.13 & 0.34 & 0 & 1 & 0.16 & 0.37 & 0 & 1 & 0.15 & 0.35 & 0 & 1 \\
\hline Fert & 3.14 & 3.08 & 0 & 18 & 3.07 & 3.03 & 0 & 18 & 3.09 & 3.05 & 0 & 18 \\
\hline Edpr & 0.19 & 0.39 & 0 & 1 & 0.18 & 0.39 & 0 & 1 & 0.19 & 0.39 & 0 & 1 \\
\hline Edsec & 0.33 & 0.47 & 0 & 1 & 0.37 & 0.48 & 0 & 1 & 0.35 & 0.48 & 0 & 1 \\
\hline Edhigh & 0.08 & 0.27 & 0 & 1 & 0.09 & 0.29 & 0 & 1 & 0.09 & 0.28 & 0 & 1 \\
\hline Working & 0.68 & 2.62 & 0 & 1 & 2.79 & 4.33 & 0 & 96 & 2.74 & 3.65 & 0 & 96 \\
\hline Lowinco & 0.20 & 0.40 & 0 & 1 & 0.19 & 0.39 & 0 & 1 & 0.19 & 0.39 & 0 & 1 \\
\hline Midleinc & 0.19 & 0.39 & 0 & 1 & 0.21 & 0.04 & 0 & 1 & 0.20 & 0.40 & 0 & 1 \\
\hline Higherinc & 0.18 & 0.39 & 0 & 1 & 0.22 & 0.41 & 0 & 1 & 0.20 & 0.40 & 0 & 1 \\
\hline FamP & 0.48 & 1.19 & 0 & 1 & 0.51 & 1.14 & 0 & 1 & 0.49 & 1.16 & 0 & 9 \\
\hline KnoV & 2.55 & 2.91 & 1 & 9 & 1.85 & 2.30 & 1 & 9 & 2.18 & 2.63 & 1 & 9 \\
\hline Age & 28.65 & 9.49 & 15 & 49 & 28.86 & 9.69 & 15 & 49 & 28.76 & 9.59 & 15 & 49 \\
\hline Agesqu & 910.8 & 590.0 & 225 & 2401 & 926.9 & 602.7 & 225 & 2401 & 919.4 & 596.9 & 225 & 2401 \\
\hline Urb & 0.31 & 0.46 & 0 & 1 & 0.40 & 0.49 & 0 & 1 & 0.36 & 0.48 & 0 & 1 \\
\hline $\mathrm{Sib}$ & 5.41 & 2.69 & 0 & 19 & 5.35 & 2.64 & 0 & 1 & 5.38 & 2.67 & 0 & 19 \\
\hline Cul & 14.38 & 30.62 & 0 & 99 & 9.01 & 24.13 & 0 & 99 & 11.49 & 27.45 & 0 & 99 \\
\hline
\end{tabular}




\section{Results and Discussion}

Table 3 shows the logistic regression results for the contraceptives use model for 2013, 2018 and both years combined. The results were interpreted using marginal effects because the coefficients cannot be interpreted as the change in the expected count for a unit change in explanatory variable (Wooldridge, 2010). The results show that variables that are significant in 2013 are also significant in 2018 and variables that are negatively or positively signed in 2013 also have the same signs in 2018. This means that the determinants of contraceptives use by women in Nigeria are not significantly different for both years. This is an important contribution of this study and this is a key message for any policy design on fertility in Nigeria. Women's schooling significantly impacts the probability of using contraceptives. The coefficients of primary, secondary and tertiary education are significantly positive, indicating that women's education increases the chances of contraceptives use. The marginal effect shows that if a woman has primary or secondary or tertiary education, the likelihood of contraceptives use increases by a factor of $0.185,0.238$ and 0.252 respectively. These results are consistent with a priori expectations. The results further confirmed that women's education increases receptivity of awareness and contraceptives use to control fertility. This is consistent with Bertrand, (1993) who found that education affect the distribution of authority within the households, whereby women may increase their authority with husbands and affect fertility and Adjei, Daniel, Jacob Owusu Sarfo and Michael Asiedu (2014) study also corroborate this result. Working women are more likely to use contraceptives. Household income measured as low-income, middle-income and high-income show that both low and middle income women are less likely to use contraceptives while high-income women are more likely to use contraceptives. But, only the coefficients of low-income and high-income are statistically significant.

The awareness of local family planning programme (famP) significantly impacts the probability of contraceptives use. The marginal effect shows that if a woman is aware of family planning programme, the likelihood of contraceptives use increases by a factor of about $2 \%$. Correct knowledge of a woman's ovulatory cycle is negatively statistically significant at $1 \%$ level. Its marginal effect suggests that a woman awareness of her ovulatory cycle is likelihood to reduce the use of contraceptives by a factor of $1.1 \%$. This suggests that women who know when they are likely to conceive are unlikely to use contraceptives. Woman's age and the square of age suggest that women in their reproductive years are more likely to use contraceptives but the usage reduces as they grow old. Women with many siblings are less likely to exercise contraception. The marginal effect suggests absence of any relationship between number of siblings and contraception. Finally, son preference appears as one of the major obstacles to contraceptives use. Son preference (cul) is 
negative and statistically significant at one $1 \%$ level but not different from zero. Its marginal effect shows that son's preference decreases the likelihood of contraceptives use by a factor of 0.0008 . This is consistent with a priori expectation that women who desired sons may not use contraceptives as long as they do not have the preferred number of son. 
Table 3: Logistic Regressions Results for Contraceptives Use

\section{DEPENDENT VARIABLE: CONTRACEPTIVES USE}

\begin{tabular}{|c|c|c|c|c|c|c|c|c|c|c|c|c|}
\hline \multicolumn{9}{|c|}{ DEPENDENT VARIABLE: CONTRACEPTIVES USE } & \multirow{2}{*}{\multicolumn{4}{|c|}{ Combined Years $(2013 \&$ 2018) }} \\
\hline \multicolumn{5}{|c|}{2013} & \multicolumn{4}{|c|}{2018} & & & & \\
\hline \multicolumn{2}{|l|}{$\begin{array}{l}\text { Logistic } \\
\text { Regression }\end{array}$} & & \multicolumn{2}{|c|}{$\begin{array}{l}\text { Marginal } \\
\text { Effect }\end{array}$} & \multicolumn{2}{|c|}{$\begin{array}{l}\text { Logistic } \\
\text { Regression }\end{array}$} & \multicolumn{2}{|c|}{$\begin{array}{l}\text { Marginal } \\
\text { Effect }\end{array}$} & \multicolumn{4}{|c|}{\begin{tabular}{|l|l}
\multicolumn{2}{c}{ Combined Years $(2013 \propto 2018)$} \\
Logistic & Marginal Effect
\end{tabular}} \\
\hline Variables & Coeff & \begin{tabular}{|l|} 
Std. \\
Error
\end{tabular} & Dy/dx & $\begin{array}{l}\text { Std. } \\
\text { Error }\end{array}$ & Coeff & $\begin{array}{l}\text { Std. } \\
\text { Error }\end{array}$ & Dy/dx & $\begin{array}{l}\text { Std. } \\
\text { Error }\end{array}$ & Coeff & $\begin{array}{l}\text { Std. } \\
\text { Error }\end{array}$ & Dy/dx & $\begin{array}{l}\text { Std. } \\
\text { Error }\end{array}$ \\
\hline Edpr & $0.88 *$ & 0.12 & 0.14 & 0.02 & $1.35 *$ & 0.11 & 0.22 & 0.02 & $1.14 *$ & 0.08 & 0.19 & 0.01 \\
\hline Edsec & $1.29 *$ & 0.11 & 0.21 & 0.02 & $1.62 *$ & 0.11 & 0.26 & 0.02 & $1.46^{*}$ & 0.08 & 0.24 & 0.01 \\
\hline Edhigh & $1.40 *$ & 0.13 & 0.22 & 0.02 & $1.68 *$ & 0.12 & 0.27 & 0.18 & $1.55^{*}$ & 0.09 & 0.25 & 0.01 \\
\hline Working & $0.03 * *$ & 0.01 & -0.00 & 0.00 & $0.01 * *$ & 0.01 & 0.00 & 0.00 & $0.02 * *$ & 0.01 & 0.00 & 0.00 \\
\hline Lowinc & $-0.27 * *$ & 0.12 & -0.04 & 0.02 & $-0.48 * *$ & 0.11 & -0.08 & 0.02 & $-0.38^{*}$ & 0.08 & -0.06 & 0.01 \\
\hline Midleinc & -0.08 & 0.09 & -0.01 & 0.02 & -0.08 & 0.08 & -0.14 & 0.01 & -0.08 & 0.06 & -0.01 & 0.01 \\
\hline Highinco & $0.34 *$ & 0.08 & 0.05 & 0.01 & $0.39 *$ & 0.07 & 0.06 & 0.01 & $0.37 *$ & 0.05 & 0.06 & 0.01 \\
\hline FamP & $0.07 * *$ & 0.03 & 0.01 & 0.00 & $0.10^{* *}$ & 0.02 & 0.02 & 0.00 & $0.09 *$ & 0.02 & 0.01 & 0.00 \\
\hline Knov & $-0.00 * *$ & 0.01 & -0.00 & 0.00 & $-0.08 * *$ & 0.03 & -0.01 & 0.00 & $-0.03 * *$ & 0.01 & -0.00 & 0.00 \\
\hline Age & 0.19 & 0.03 & 0.03 & 0.01 & 0.18 & 0.03 & 0.03 & 0.00 & $0.19 *$ & 0.02 & 0.03 & 0.00 \\
\hline Agesqu & $-0.01 *$ & 0.01 & -0.00 & 0.00 & $-0.01 *$ & 0.01 & -0.00 & 0.00 & $-0.01 *$ & 0.01 & -0.00 & 0.00 \\
\hline Urb & $0.17 * *$ & \begin{tabular}{|l|}
0.07 \\
\end{tabular} & 0.03 & 0.01 & $0.00 * *$ & 0.06 & 0.01 & 0.01 & 0.07 & 0.05 & 0.01 & 0.01 \\
\hline $\mathrm{Sib}$ & $-0.03 *$ & \begin{tabular}{|l|}
0.01 \\
\end{tabular} & -0.00 & 0.00 & $-0.03 *$ & 0.01 & -0.00 & 0.00 & $-0.02 *$ & 0.01 & -0.00 & 0.00 \\
\hline Cul & $-0.01 *$ & 0.00 & -0.00 & 0.00 & $-0.00 *$ & 0.00 & -0.00 & 0.00 & $-0.01 *$ & 0.00 & -0.00 & 0.00 \\
\hline Const & -5.77 & 0.48 & & & -5.68 & 0.41 & & & -5.73 & 0.31 & & \\
\hline & $\begin{array}{l}\text { Chi2 }=5 \\
\mathrm{P}=0.00 \\
\text { Pseudo } \\
\text { No of } \mathrm{O}\end{array}$ & $\begin{array}{l}7.49 \\
=0.0859 \\
\text { ervation }\end{array}$ & & & $\begin{array}{l}\text { F-test }=8 \\
P=0.00 \\
\text { Pseudo } \\
\text { No of } \mathrm{Ol}\end{array}$ & $\begin{array}{l}3 \\
=0.093 \\
\text { rvation }\end{array}$ & & & $\begin{array}{l}\text { Chi2 = 1 } \\
0.0000 \\
0.0885\end{array}$ & $\begin{array}{l}7.51 \\
\text { of Obse }\end{array}$ & tion $=1$ & $\begin{array}{l}P= \\
\text { eudo } R^{2}= \\
54\end{array}$ \\
\hline
\end{tabular}


Table 4 shows the negative binomial regression results for the fertility model. The results show the same trend like the contraceptive use results. The results show that variables that are significant in 2013 are also significant in 2018 and variables that are negatively or positively signed in 2013 also have the same signs in 2018. Women's schooling significantly reduces the number of children born per woman. All the measures of women's schooling are significantly negative. The marginal effect of the primary, secondary and tertiary education implies that the probability of having more children is 0.35 , 1.14 and 2.23 lower for women who have primary, secondary and tertiary education respectively. These results are consistent with the studies of Ainsworth, (1996) and Martin \& Juarez, (1995). It can also be seen that reduction in women's fertility increase with an increase in education level. Working women are less likely to have many children. Household income measured as low, middle and high-income show that low and middle-income women are likely to have more children than high-income women. This finding reflects the strong impact of mother's income on the time cost of children. The results support Becker (1965) who concluded that child care is a time intensive activity that is not productive (in terms of earnings) and uses many hours that could be used at work which is earnings-intensive activity and predicted that the opportunity cost of childbearing is higher to highincome families.

Family planning programmes are expected to have a negative effect on fertility. However, the coefficient is positive, but not significantly different from zero. Inadequate health care centres in rural areas could be a possible explanation for this since rural women are about $64 \%$ of the total survey women. The knowledge of ovulatory cycle $(\mathrm{knoV})$ is negative and statistically significant at $1 \%$ level indicating that woman knowledge of her ovulatory cycle may decrease the number of children born. Woman knowledge of her ovulatory cycle decreases the expected number of children born by a probability of about 0.031 . The use of contraceptive also significantly lowers number of children born per woman. The coefficient of contraception is negatively significant at $1 \%$ level, indicating that as contraceptives use increases, the number of children born per woman decreases by a factor of about 3\%. This is consistent with the findings of Rutenberg, Ayad, Ochoa \& Wilkinson, (1991) who found that the primary cause of fertility declines in many developing countries is the increase use of effective family planning methods. Women's age is positive and significant which is consistent with a priori expectation. Given that the mean age of the surveyed women is 28 , suggesting that most of the women are in their childbearing age. The probability of the number of children implies that the responsiveness of a woman's age increases the expected number of children born by a probability of 0.168 . 
Place of residence is negative and statistically significant at $1 \%$ level, indicating an inverse relationship between women fertility and her place of residence. The marginal effect suggests that if a woman resides in an urban area, the expected number of children decreases by a probability of 0.14 . This finding is supported by Ainsworth, (1996) and Colleran, (2014). The number of siblings (sib) a woman has also has a significant impact on the number of children per woman. The statistically significant coefficient indicates that inter-generational inheritance of family size preference has a direct influence on fertility. The marginal effect indicates that the number of siblings increases the expected number of children by a factor of 0.06 . This implies that women are likely to mimic the reproductive behaviour of their parents. Lastly, son preference (cul) increases the expected number of children by a factor of $0.3 \%$. That is women who have son preference may reproduce until they get the desired number of sons. This is consistent with Hank and Hans-Kohler (2002) who argued that parents who desire one or more children of a certain sex would tend to have larger families. 
Table 4: Negative Binomial Results for Fertility Model

\section{DEPENDENT VARIABLE: FERTILITY} 2013

\begin{tabular}{|c|c|c|c|c|c|c|c|c|c|c|c|c|}
\hline \multicolumn{5}{|c|}{2013} & \multicolumn{4}{|c|}{2018} & \multicolumn{4}{|c|}{ Combined Years $(2013 \&$ 2018) } \\
\hline \multicolumn{3}{|c|}{$\begin{array}{l}\text { Negative } \\
\text { Binomial } \\
\text { Regression }\end{array}$} & \multicolumn{2}{|c|}{$\begin{array}{l}\text { Marginal } \\
\text { Effect }\end{array}$} & \multicolumn{2}{|c|}{$\begin{array}{l}\text { Negative } \\
\text { Binomial } \\
\text { Regression }\end{array}$} & \multicolumn{2}{|c|}{$\begin{array}{l}\text { Marginal } \\
\text { Effect }\end{array}$} & \multicolumn{2}{|c|}{$\begin{array}{l}\text { Negative } \\
\text { Binomial } \\
\text { Regression }\end{array}$} & \multicolumn{2}{|c|}{$\begin{array}{l}\text { Marginal } \\
\text { Effect }\end{array}$} \\
\hline Variables & Coeff & $\begin{array}{l}\text { Std. } \\
\text { Error }\end{array}$ & $\mathrm{dy} / \mathrm{dx}$ & $\begin{array}{l}\text { Std. } \\
\text { Error }\end{array}$ & Coeff & $\begin{array}{l}\text { Std. } \\
\text { Error }\end{array}$ & $d y / d x$ & $\begin{array}{l}\text { Std. } \\
\text { Error }\end{array}$ & Coeff & $\begin{array}{l}\text { Std. } \\
\text { Error }\end{array}$ & $\mathrm{dy} / \mathrm{dx}$ & $\begin{array}{l}\text { Std. } \\
\text { Error }\end{array}$ \\
\hline Edpr & $-0.99 *$ & 0.02 & -0.26 & 0.05 & $-0.15 *$ & 0.02 & -0.39 & 0.05 & $-0.13^{*}$ & 0.01 & -0.35 & 0.04 \\
\hline Edsec & $-0.41 *$ & 0.02 & -1.13 & 0.06 & $-0.41 *$ & 0.02 & -1.13 & 0.05 & $-0.41 *$ & 0.01 & -1.14 & 0.04 \\
\hline Edhigh & $-0.77 *$ & 0.03 & -2.17 & 0.08 & $-0.72 *$ & 0.03 & -2.01 & 0.07 & $-0.74 *$ & 0.02 & -2.04 & 0.05 \\
\hline Working & $0.01 *$ & 0.01 & -0.00 & 0.00 & $0.00 * *$ & 0.00 & 0.00 & 0.00 & -0.01 & 0.00 & 0.01 & 0.01 \\
\hline Lowinc & $0.06 * *$ & 0.02 & 0.17 & 0.06 & $0.03 *$ & 0.02 & 0.07 & 0.05 & $0.04 *$ & 0.01 & 0.12 & 0.04 \\
\hline Midleinc & $0.04 *$ & 0.02 & 0.13 & 0.05 & $0.02 *$ & 0.02 & 0.06 & 0.05 & $0.03 * *$ & 0.01 & 0.08 & 0.04 \\
\hline Highinc & $-0.10 *$ & 0.02 & -0.29 & 0.06 & $-0.12 * *$ & 0.02 & -0.32 & 0.05 & $-0.11 *$ & 0.01 & -0.29 & 0.04 \\
\hline Fam & $0.02 *$ & 0.01 & 0.07 & 0.02 & $0.01 *$ & 0.01 & 0.03 & 0.02 & $0.02 *$ & 0.00 & 0.05 & 0.01 \\
\hline Knov & $-0.01 * *$ & 0.01 & -0.03 & 0.01 & $-0.02 *$ & 0.00 & -0.05 & 0.01 & $-0.01 *$ & 0.00 & -0.03 & 0.01 \\
\hline Age & $0.06 *$ & 0.01 & 0.17 & 0.00 & $0.06 *$ & 0.00 & 0.17 & 0.00 & $0.06^{*}$ & 0.00 & 0.17 & 0.00 \\
\hline Contr & 0.12 & 0.02 & 0.33 & 0.05 & 0.13 & 0.02 & 0.35 & 0.04 & $0.12 *$ & 0.01 & 0.34 & 0.03 \\
\hline Urb & $-0.05 * *$ & 0.01 & -0.13 & 0.05 & $-0.05^{*}$ & 0.01 & -0.13 & 0.04 & $-0.51 *$ & 0.01 & -0.14 & 0.03 \\
\hline $\mathrm{Sib}$ & $0.02 *$ & 0.00 & 0.01 & 0.01 & $0.03 *$ & 0.00 & 0.03 & 0.00 & $0.02 *$ & 0.00 & 0.06 & 0.01 \\
\hline $\mathrm{Cul}$ & $0.01 *$ & 0.00 & 0.00 & 0.00 & $0.00 *$ & 0.00 & 0.00 & 0.00 & $0.00 *$ & 0.00 & 0.00 & 0.00 \\
\hline Const & $-0.63 *$ & 0.04 & & & $-0.62 *$ & 0.04 & & & -0.62 & 0.03 & & \\
\hline \multicolumn{5}{|c|}{$\begin{array}{l}\text { Chi } 2=5253.31 \\
P=0.0000 \\
\text { Pseudo } R^{2}=0.1787 \\
\text { Number of Observation }=6411\end{array}$} & \multicolumn{4}{|c|}{$\begin{array}{l}\text { Chi2 }=6710.20 \\
\mathrm{P}=0.0000 \\
\text { Pseudo } \mathrm{R}^{2}=0.1672 \\
\text { Number of Observation }=8843\end{array}$} & \multicolumn{4}{|c|}{$\begin{array}{l}\text { Chi2 }=11916.18 \\
\mathrm{P}=0.0000 \\
\text { Pseudo } \mathrm{R}^{2}=0.1714 \\
\quad \text { Number of Observation }=15254\end{array}$} \\
\hline
\end{tabular}




\section{Conclusion}

This study examines the influence of female education on the use of contraceptives in Nigeria using 2013 and 2018 cohorts of demography and health survey data. The study found a direct impact of women's schooling on contraceptives use in Nigeria. Also, the study establishes evidence of a negative impact of female's education on fertility rate. The study further corroborates the impacts of cultural factors and preference for a male child on fertility rate. It shows that contraceptives use and fertility rate are commonly influenced by educational level, work, income, age, place of residence and preference for a male child. Notably, there is common behavioural patterns in 2013 and 2018 NDHS data. This is an indication of absence of significant difference in the factors that influenced contraceptives use and fertility rate in Nigeria. Therefore, the study concludes that investment in women's education should be a priority to encourage more use of contraceptives and control women fertility rate. Therefore, more investment should be made on women education to increase women use of contraceptives, control fertility, protect women's health and rights, and promote sustainable economic development.

\section{References:}

1. Adjei Daniel Jacob, Owusu Sarfo, Michael Asiedu and Isaac Acheampong Sarfo (2014) Psychosocial Factors Affecting Contraceptive Usage: A Case of Unmet Needs in Ghana European Scientific Journal vol.10 (15) ISSN: 1857 - 7881 (Print) e - ISSN 1857- 7431

2. Ainsworth, M., Beegle, K., \& Nyamete, A. (1996) The impact of women's schooling on fertility and contraceptive use: A Study of fourteen Sub-Saharan African countries. World Bank Development Report, 85-122.

3. Ayoub, A. S. (2003). An economic analysis of women's schooling on fertility and contraceptive use in developing countries: A case study of Tanzania. UNLV Restrospective Thesis and Dissertations, 26-33.

4. Becker, G. S. (1965). A theory of the allocation of time. The Economic Journal, 75, 493-517.

5. Bledsoe, Casterline, John, B., John, B., \& Kuhn, J. (1999). Critical perspectives on schooling and fertilitv in the developing world. Academy Press.

6. Bongaarts, J., Frank , O., \& Lesthaeghe, R. (1984). The proximate determinants of fertility in Sub-Saharan Africa. Population and Development Review., 511-537.

7. Buckley C, B. J. (2004). Reproductive and sexual health among young adults in Uzbekistan. Stud Fam Plann 2004 , 4-14. 
8. Charlie, G. (2003). women's education and contraceptive use in Ethiopia. internation journal of education, 30-45.

9. Edward, B. (2011). Female Education, Contraceptive Use, and Fertility: Evidence from Uganda. The Journal of Sustainable Development, 20-47.

10. Jejeebhoy, S. J. (1995). Women's education, autonomy, and reproductive behavior: Experience from developing countries. Oxford: Clarendon Press.

11. Lesthaeghe Ron , R. J., \& Moors, G. (1992). Dynamics of cohort and genera- tions research. Population and Devel- opment Review, , 165202.

12. Martin C, T. C. (1995). Women's education and fertility: Results from 26 demographic and health surveys. Studies in Familv Planning, 187 202.

13. Martin, C. a. (1995). The impact of women's education on fertility in Latin America: Searching for explanation. International Family Perspective, 52-57.

14. McCrary, J. a. (2011). "The effect of female education on fertility and infant health: Evidence from school entry policies using exact date of birth . American Economic Review , 158-165.

15. Michael, R. T. (1973). Education and the derived demand for children: New Economic Approaches to fertility. the journal of political economy, 128.

16. Monjok , E., Smesny , A., ekabua, J., \& Essien , J. (2016). Contraceptive practices in Nigeria: Literature review and recommendation for future policy decisions. Open Access Journal of Contraception, 9.

17. Muhuri, P. K. (1994). Bangladesh demographic and health survey 1993-4. National Institute of Population Research and Training.

18. Musyoka, Peter K., Julius Korir, Jacob Omolo and Charles C. Nzai (2018) An Empirical Analysis of the Effect of Poverty on Health Care Utilization in Kenya. European Scientific Journal, Vol.14 (22) ISSN:1857 - 7881 (Print)e-ISSN 1857- 7431.

Doi:10.19044/esj.2018.v14n22p101

19. Obomeghie Muhammed A., Idris Abubakar and Yerima Isah Abdulrahman (2018) The Impact of Net-Migration on Total Fertility Rate in Sub-Sahara African Countries: Empirical Evidence from Nigeria. European Scientific Journal Vol.14 (11) ISSN: 1857 - 7881 (Print) e - ISSN 1857- 7431. Doi: 10.19044/esj.2018.v14n11p34

20. Savage-Oyekunle, Oluremi A. (2018) Appraisal of Nigeria's Obligation on Adolescents' Access to Sexual and Reproductive Health 
Care. European Scientific Journal February 2018 Vol.14 (6) ISSN: 1857 - 7881 (Print) e - ISSN 1857- 7431

Doi: 10.19044/esj.2018.v14n6p466

21. Todaro, M. S. (2015). Economic Development (12th ed.). (12 ed.). UK: Pearson Education limited.

22. Ugoji , F. N. (2013). An Examination of University Students' Attitude to Contraceptive Use. American International Journal of Social Science, 21-22.

23. Wooldridge, J. M. (2010). Econometric Analysis of Cross Section and Panel Data. Massachusetts London, England: The MIT Press Cambridge. 